\title{
Thermal tolerance and potential distribution of invasive lionfish (Pterois volitans/miles complex) on the east coast of the United States
}

\author{
Matthew E. Kimball ${ }^{1,2,3}$, John M. Miller ${ }^{2}$, Paula E. Whitfield ${ }^{1}$, Jonathan A. Hare ${ }^{1, *}$ \\ ${ }^{1}$ Center for Coastal Fisheries and Habitat Research, NOAA Beaufort Laboratory, 101 Pivers Island Road, Beaufort, \\ North Carolina 28516, USA \\ ${ }^{2}$ Department of Zoology, Campus Box 7617, North Carolina State University, Raleigh, North Carolina 27695-7617, USA \\ ${ }^{3}$ Present address: Rutgers University Marine Field Station, 800 c/o 132 Great Bay Boulevard, Tuckerton, \\ New Jersey 08087-2004, USA
}

\begin{abstract}
The occurrence of lionfish (Pterois volitans/miles) complex on the southeast United States shelf represents one of the first documented invasions of a Pacific marine fish species into the western Atlantic Ocean. Temperature has been proposed as a possible factor limiting the range of this introduction. To examine this hypothesis, temperature-tolerance studies were conducted following the chronic lethal minimum protocol, with death as the endpoint. Overall, the mean chronic lethal minimum was $10.0^{\circ} \mathrm{C}$ and mean temperature at feeding cessation was $16.1^{\circ} \mathrm{C}$. Rate of temperature decrease and acclimation temperature did not have a significant effect on chronic lethal minimum or temperature at feeding cessation. When combined with mean February water temperatures, lionfish thermal tolerance data indicated that lionfish could overwinter on the southeast United States continental shelf, with a northern limit of Cape Hatteras and an inshore limit coincident with the mean $12^{\circ} \mathrm{C}$ isotherm, which equates to a $10^{\circ} \mathrm{C}$ minimum water temperature. The mean $12^{\circ} \mathrm{C}$ bottom isotherm also runs along the continental shelf break (200 $\mathrm{m}$ isobath), marking the offshore limit for lionfish on the southeast United States continental shelf. The current southern limit of the invasion is not bound by temperature, as lionfish could survive (but have not yet been reported) on the Florida coast south of Miami, throughout the Gulf of Mexico and Caribbean Sea, extending into the southern hemisphere. Possible reasons for the constrained southern limit may include planktonic transport mechanisms, patterns of juvenile and adult movements, and the initial lionfish introduction site.
\end{abstract}

KEY WORDS: Marine introduction · Biological invasion $\cdot$ Lionfish $\cdot$ Pterois volitans $\cdot$ Pterois miles Invasive species $\cdot$ Species range limits $\cdot$ Temperature tolerance

Resale or republication not permitted without written consent of the publisher

\section{INTRODUCTION}

Lethal temperature limits the geographic distribution and movement of aquatic species (Brett 1956). In general, studies on low temperature tolerance have been undertaken to predict whether or not a species is capable of overwintering (Beitinger et al. 2000), and the majority of temperature-tolerance data have been generated for temperate fish species (Brett 1956, Elliot 1981, Beitinger et al. 2000), with scant information for tropical fishes (but see Bennett et al. 1997 and Mora \&
Ospina 2002). The fact that cold temperatures are not an obvious threat to fish survival in tropical waters (Bennett \& Judd 1992), coupled with historically conservative estimates of the general thermal limits of tropical fish faunas (e.g. $20^{\circ} \mathrm{C}$ limit, Briggs 1974), may have limited interest in examining thermal tolerances in tropical fishes. Yet, with the expansion of tropical species into temperate waters, potentially related to climate change (Parker \& Dixon 1998), and the increasing number of marine invasions (Randall 1987, Baltz 1991, Golani \& Sonin 1992, Ruiz et al. 1997, Erdmann \& 
Vagelli 2001, Semmens et al. 2004), information on the thermal tolerances of tropical fishes is vital.

Lionfish (Pterois volitans/miles complex ${ }^{1}$ ) are native to tropical coral reefs and range from the southern Indian Ocean, east to Sumatra and throughout the Indo-West Pacific from southern Japan to central Australia (Schultz 1986). They are typically found from shore $(0 \mathrm{~m})$ to approximately $50 \mathrm{~m}$ (Schultz 1986). Since the year 2000, adult and juvenile lionfish have been observed on the mid- and outer-continental shelf (20 to $80 \mathrm{~m}$ ) off the southeast United States (Whitfield et al. 2002). Determining the potential range of lionfish is a first step in examining and predicting the effects of lionfish on species and ecosystems in the western Atlantic Ocean (Hare \& Whitfield 2003).

Thermal limits have been identified as a possible factor defining the distribution of the invasive lionfish along the east coast of the United States (Whitfield et al. 2002). Faunal distribution and temperature regimes in the region indicate that Cape Hatteras forms the northern barrier for the warm-temperate fauna in the western Atlantic Ocean (Briggs 1974). This faunal separation can be attributed to the effects of temperature, acting as both a limiting factor determining species distribution, and a directive factor guiding species movement (Fry 1971; see also Cossins \& Bowler 1987 for coverage of thermal regulation of species distribution). The abrupt difference in inshore water temperature south and north of Cape Hatteras (Stegmann \& Yoder 1996), along with the majority of lionfish observations located south of Cape Hatteras, suggests that temperature is an important factor limiting distribution. Further, the incongruence between the inshore distribution of lionfish in their native range and their primarily offshore distribution in their introduced range could be a result of temperature-limited distribution during winter (Whitfield et al. 2002). Thus winter water temperature along the United States Atlantic coast may define habitat suitable for lionfish survival, maturation and reproduction. Due to their high sitefidelity and stationary behavior after larval settlement (Fishelson 1975, 1997), individuals occurring outside thermally suitable winter habitats during warmer months (e.g. Long Island, New York; see Whitfield et al. 2002, Hare \& Whitfield 2003) will be likely to suffer overwinter mortality as waters cool.

\footnotetext{
${ }^{1}$ Schultz (1986) concluded that Pterois volitans and P. miles were allopatric sibling species, with $P$. volitans occurring largely in the western Pacific and $P$. miles in the Indian Ocean. A recent study showed genetic separation between $P$. volitans and $P$. miles, but was inconclusive as to whether there were 2 separate species or 2 populations of a single species (Kochzius et al. 2003). Herein, the 2 are referred to as the $P$. volitans/miles complex and termed commonly as lionfish
}

The present study examined the potential effects of temperature, rate of temperature decline and acclimation temperature on overwintering success and distribution patterns of lionfish on the southeast United States continental shelf. Laboratory temperature-tolerance studies have been used to examine temperaturelimited distributions of both invasive and non-invasive species: red-bellied piranha Pygocentrus nattereri in the United States (Bennett et al. 1997), southern flounder Paralichthys lethostigma in Texas estuaries (Prentice 1989), Atlantic croaker Micropogonias undulatus in mid-Atlantic estuaries (Lankford \& Targett 2001), and 14 introduced freshwater fishes in Florida (Shafland \& Pestrak 1982). Temperature data for the southeast continental shelf were combined with experimentally determined low temperature tolerances to create a map of potential lionfish habitat in introduced waters.

\section{MATERIALS AND METHODS}

Chronic lethal methodology (Beitinger et al. 2000) was used to determine the temperature tolerance of lionfish, with death as the endpoint (Becker \& Genoway 1979, Shafland \& Pestrak 1982, Fields et al. 1987, Prentice 1989, Zale \& Gregory 1989, Lankford \& Targett 2001). This methodology allows simulation of natural temperature conditions, as well as the assessment of key points such as feeding cessation and behavioral characteristics that may be overlooked using other methods (Doudoroff 1942, Schwartz 1963, 1964, Elliott 1981, Prentice 1989, Baker \& Heidinger 1996, Lankford \& Targett 2001, Hurst \& Conover 2002). Sudden (acute) changes of temperature, such as those experienced in low thermal plunge conditions, are not commonly found in nature (Doudoroff 1942), whereas the chronic lethal minimum gives an indication of the survival requirements of fishes in natural habitats (Bennett et al. 1997).

General approach. We conducted 3 separate experiments to quantify lionfish temperature tolerance. The first experiment evaluated the tolerance of lionfish to decreases in water temperature commonly observed on the southeast United States continental shelf during winter. The second experiment examined the effects of faster rates of temperature decline on cold tolerance. The third experiment examined the effect of acclimation temperature on cold tolerance. The results of the 3 experiments were used to estimate the overall chronic lethal minimum (CLmin.), and were then combined with temperature data from the southeast United States continental shelf to predict potential lionfish distribution.

Rate of temperature decline on the southeast United States continental shelf. A rate of temperature decline simulating natural conditions was determined from 
continuous temperature data recorded during 2001 and 2002 at various locations on the North Carolina shelf. Temperature data were obtained from 5 locations where lionfish have been observed (Fig. 1A). Sharp drops in winter (December, January, February, March) temperatures at these sites were chosen for further analysis (Fig. 1B). The average duration of 19
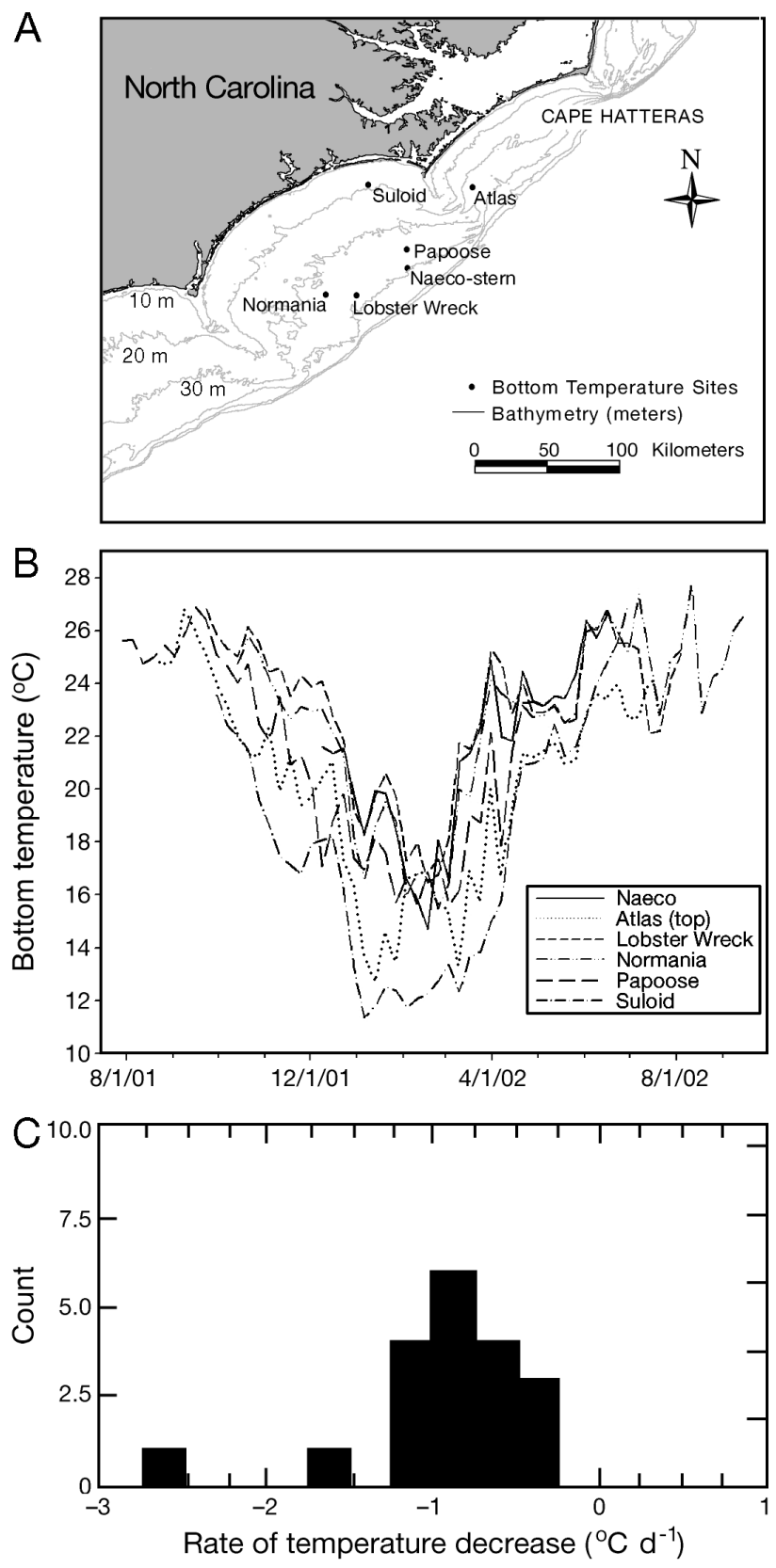

Fig. 1. (A) Location of shipwrecks along North Carolina coast where temperature loggers were deployed; Bathymetry shown to $60 \mathrm{~m}$. Only 10, 20, and $30 \mathrm{~m}$ isobaths are labeled. Lionfish have been observed at all sites except the Suloid. (B) Bottom temperatures recorded at each wreck site in (A) during winter of 2001 to 2002. (C) Rate of temperature decline for 19 cold events recorded from sites in (A) decreasing temperature events was $4 \mathrm{~d}$, and the rates of decrease ranged from -0.25 to $-2.75^{\circ} \mathrm{C} \mathrm{d}^{-1}$ (Fig. 1C). The average rate of temperature decline $\left(-1^{\circ} \mathrm{C} \mathrm{d}^{-1}\right)$ was used for all experimental trials and controls, except Expt 2, which examined the effects of variable rates of temperature decline.

Lionfish husbandry and experimental setup. Juvenile lionfish were purchased from a commercial vendor (Marine Center, Dallas, Texas) for all 3 experiments. Fish averaged $8.0 \mathrm{~cm}$ standard length $(\mathrm{SD}=1.3)$. All lionfish were initially labeled by the vendor as Pterois volitans, but meristic analyses of some lionfish originating from Sumatra (origin characterized and labeled by the vendor) identified some individuals as $P$. miles. Experiments were conducted independent of species designation, owing to the uncertainty regarding species status (Kochzius et al. 2003).

Fish used in the first experiment were housed at the North Carolina Aquarium at Pine Knoll Shores and kept in two 200 gallon (757.08 1) holding tanks in a flow-through seawater system. Fish used in the second and third experiments were kept at the NOAA Beaufort Laboratory in a recirculating seawater system consisting of four 180 gallon (681.37 l) polyethylene tanks, each with an individual biofiltration unit. At both the North Carolina Aquarium and NOAA Beaufort Laboratory, temperatures were maintained at $25^{\circ} \mathrm{C}$ throughout the holding period, and salinities were maintained at 35 throughout the holding period and the duration of all experiments. Seawater for each tank was filtered and adjusted with Instant Ocean ${ }^{\circledR}$ and/or distilled water to achieve the desired salinity. Approximately 15 to $20 \%$ of the water was changed twice a month. An approximate photoperiod of $10 \mathrm{~h}$ light:14 h dark was maintained with fluorescent light at each housing facility and throughout all experiments. Lionfish were initially fed a mixture of frozen and live fishes (Anchoa spp.), but were later fed a diet of entirely live fishes (Gambusia affinis, Leiostomus xanthurus, Lagodon rhomboides, and Fundulus spp.) from local waters. Lionfish were fed to satiation every 2 to $3 \mathrm{~d}$ while in holding tanks, and offered food approximately every 1 to $2 \mathrm{~d}$ while in experimental tanks.

All individual temperature trials were conducted at the NOAA Beaufort Laboratory. Four 50 gallon (189.27 l) aquaria were used for the experimental tanks, each equipped with recirculation and refrigeration units, biological filtration, and digital thermostats. Temperature was measured and monitored using a handheld digital thermometer (accuracy $\pm 0.2^{\circ} \mathrm{C}$ ). Salinity was monitored weekly and adjusted to 35 as needed.

Expt 1. Effects of winter water temperatures. Individual lionfish were subjected to temperature decreases of $-1^{\circ} \mathrm{C} \mathrm{d}^{-1}(\mathrm{n}=10)$. Individual fish were transferred from holding tanks to experimental tanks and held for 
a period of $24 \mathrm{~h}$ before temperature manipulation. Observations and temperatures were recorded for each fish when feeding cessation, loss of equilibrium and death occurred. Death was defined as the cessation of fin, body and opercular movement and a total lack of organismic response (Becker \& Genoway 1979, Lankford \& Targett 2001).

Expt 2. Effects of rate of temperature decline. Individual lionfish were subjected to 3 rates of temperature decrease: $-3^{\circ} \mathrm{C} \mathrm{d}^{-1}(\mathrm{n}=6),-2^{\circ} \mathrm{C} \mathrm{d}^{-1}(\mathrm{n}=6)$, and $-1^{\circ} \mathrm{C}$ $\mathrm{d}^{-1}(\mathrm{n}=3)$. Individuals were randomly assigned a rate of decrease and then transferred to an experimental tank and held for $24 \mathrm{~h}$ before the start of the experiment. Observations and temperatures were recorded for each fish when feeding cessation, loss of equilibrium and death occurred.

Expt 3. Effects of acclimation temperature. Individual lionfish were acclimated to 3 temperatures $\left(15^{\circ} \mathrm{C}\right.$, $\mathrm{n}=6 ; 20^{\circ} \mathrm{C}, \mathrm{n}=6 ; 25^{\circ} \mathrm{C}, \mathrm{n}=3$ ) and then subjected to a temperature decline of $-1^{\circ} \mathrm{C} \mathrm{d}^{-1}$. To reach acclimation temperatures, water temperatures were decreased by $-1.0^{\circ} \mathrm{C} \mathrm{d}^{-1}\left( \pm 0.5^{\circ} \mathrm{C}\right)$ from the $25^{\circ} \mathrm{C}$ initial holding temperature until constant acclimation temperatures were achieved. All fish were held at the experimental acclimation temperature for at least $20 \mathrm{~d}$ prior to experimental trials. Following transfer from the holding tanks, the fish were held in the experimental tanks for $24 \mathrm{~h}$ before temperature decreases were initiated. Behavioral observations and temperatures were recorded for each fish when feeding cessation, loss of equilibrium and death occurred.

Data analyses. Mean temperatures at which death (CLmin.) and feeding cessation occurred were calculated from individual observations for each experimental treatment. Fish that did not eat during experimental trials were excluded from mean feeding cessation calculations. Analysis of variance was used to test for effects of rate of decline and acclimation temperature on CLmin. values and temperatures of feeding cessation.

Distribution and potential overwintering range. To predict the overwintering range and distribution of lionfish on the southeast United States continental shelf, long-term offshore temperature data were compared with locations of lionfish observations. From NOAA's CoastWatch program for the month of February (1995 to 2003), 382 sea surface temperature images were spatially registered automatically (data provided by R. Ferguson, NOAA Center for Coastal Fisheries and Habitat Research) and a composite image was developed from the median pixel values. Median values limited the effect of cloud cover on the composite image. Minimum temperatures in the inner southeastern continental shelf occur in February (Atkinson 1985). Isotherms representing the CLmin. and temperature at feeding cessation were extracted from the composite image and used to develop a predicted distribution for lionfish.

A potential problem of the use of sea surface temperature in predicting lionfish distribution is that surface temperature does not always represent bottom temperature, owing to stratification (Atkinson 1985). We used 2 approaches to address this issue. First, images for the period of 4 December 2001 to 28 March 2002 were browsed from the NOAA CoastWatch program. Relatively cloud-free images were chosen for subsequent analyses $(n=24)$. Sea surface temperatures were extracted and georeferenced from these relatively cloud-free images for the locations of 3 bottom temperature data-loggers using Windows Image Manager (Kahru 2001). These 3 bottom locations were chosen to represent the inner (Suloid), and outer (Papoose and Naeco) continental shelf (Fig. 1A), thereby providing a broad geographic expanse to compare shelf water temperatures and elucidate general trends between inshore and offshore waters. Sea surface temperatures were compared to corresponding bottomwater temperatures for the 2001 to 2002 winter using linear regression (Fig. 2). Regression intercepts were 3.70 and $6.68^{\circ} \mathrm{C}$ for the outer shelf locations, indicating that surface waters were warmer than bottom waters; this thermal stratification on the outer shelf probably results from the Gulf Stream water intruding onto the shelf at the surface (Atkinson 1985). In contrast, on the inner shelf, the regression intercept was $0.98^{\circ} \mathrm{C}$, indicating little thermal stratification (Atkinson 1985). This analysis supports the use of sea-surface temperature images for estimating the overwintering range and distribution of lionfish on the inner $(<30 \mathrm{~m})$ southeast United States continental shelf.

Second, isotherms from the median February sea surface temperature image were compared with average

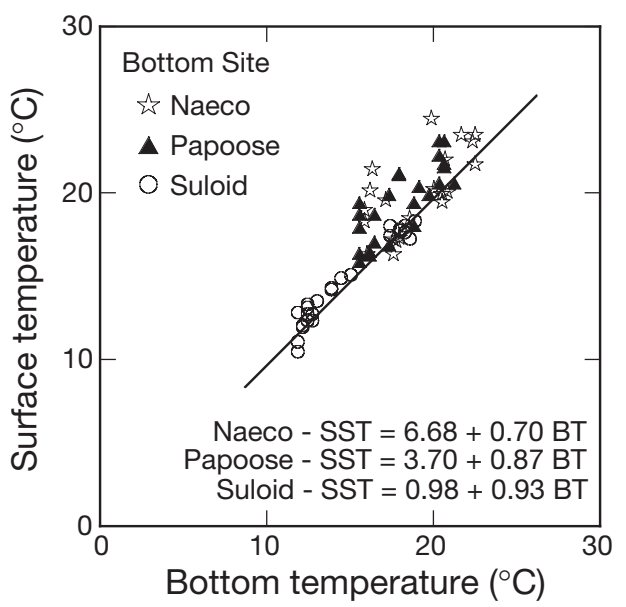

Fig. 2. Satellite-derived sea surface temperature (SST) and bottom temperature (BT) at 3 North Carolina wreck sites: Naeco $(r=0.671)$, Papoose $(r=0.796)$, and Suloid $(r=0.973)$. Linear regression equation for each site is provided 
February bottom temperatures. Average February bottom temperatures were derived from National Oceanographic Data Center profiles $(n=5000)$ for the years 1950 to 1999 and organized into a grid of monthly averages (data reported in Blanton et al. 2003 and provided by B. Blanton, University of North Carolina at Chapel Hill). Median sea-surface temperature isotherms corresponded closely with average bottom temperature isotherms (Fig. 3). The concordant results of both approaches support the use of median sea-surface temperatures as a proxy for average bottom-water temperatures on the inner-shelf during winter months. For offshore bottom temperatures, however, the average bottomtemperature data of Blanton et al. (2003) is required. Satellite data was used because it provides water temperatures over a broader spatial domain.

\section{RESULTS}

\section{Expt 1. Effects of winter water temperatures}

Lionfish exhibited a highly consistent pattern of behavior when subjected to gradual temperature decrease. After transfer to experimental tanks, all fish exhibited normal behavior; they were responsive to visual and physical stimuli, had slow opercular ventilation, and explored their surroundings. At temperatures of $13^{\circ} \mathrm{C}$ and below, fish were unresponsive to visual stimuli (but still responded to touch), displayed darker coloration, and became stationary and lethargic. Once stationary, all fish positioned dorsal, pectoral and pelvic fins against their body and oriented themselves into a corner of the tank for the remainder of the experiment. Temporary loss of equilibrium and swimming bursts were observed at temperatures just prior to death, with permanent loss of equilibrium at tempera- tures at which death occurred. Swimming bursts usually consisted of swimming rapidly for 3 to $5 \mathrm{~s}$ (occasionally bumping into tank walls) followed by total cessation of movement, at which point the fish sank to the bottom and remained motionless. All fish fed prior to experimental trials. The majority of fish fed at or below the initial temperature setting, with only 1 fish not eating throughout the entire trial. Fish generally ate less at lower temperatures and no fish was observed feeding below $13^{\circ} \mathrm{C}$. The mean CLmin. value was $10.7^{\circ} \mathrm{C}$, with very little variation $(\mathrm{SD}=0.5, \mathrm{n}=10$; Fig. 4A). The mean temperature at feeding cessation was $15.3^{\circ} \mathrm{C}(\mathrm{SD}=2.0, \mathrm{n}=9$; Fig. $4 \mathrm{~B})$.

\section{Expt 2. Effects of rate of temperature decline}

Fish generally followed the behavior patterns observed in Expt 1. All fish in the $-3^{\circ} \mathrm{C} \mathrm{d}^{-1}$ group displayed normal behavior until temperature was decreased to $13^{\circ} \mathrm{C}$, at which point they became lethargic and stationary. Temporary loss of equilibrium and swimming bursts began to occur at $10^{\circ} \mathrm{C}$. These changes in behavior were rapidly followed by permanent loss of equilibrium and death for all individuals in this group. Those fish exposed to $\mathrm{a}-2^{\circ} \mathrm{C} \mathrm{d}^{-1}$ rate of decrease behaved similarly. At $13^{\circ} \mathrm{C}$, the majority of fish became stationary and lethargic. After the temperature was decreased to $11^{\circ} \mathrm{C}$, all fish experienced temporary loss of equilibrium and swimming bursts. Again, these changes in behavior were followed rapidly by permanent loss of equilibrium and death, with several individuals observed resting upside down on the tank bottom just prior to death; 1 fish from this group was eliminated from the analyses due to death from causes other than low temperature. Fish from the $-1^{\circ} \mathrm{C} \mathrm{d}^{-1}$ group behaved similarly to those from Expt 1.
Fig. 3. Bottom temperature isotherms for February, derived from 1950 to 1999 bottom temperature climatology (BTC) of the southeast United States continental shelf (from Blanton et al. 2003) and satellitederived sea surface temperature isotherms developed as part of this study. NC, SC: North and South Carolina, respectively
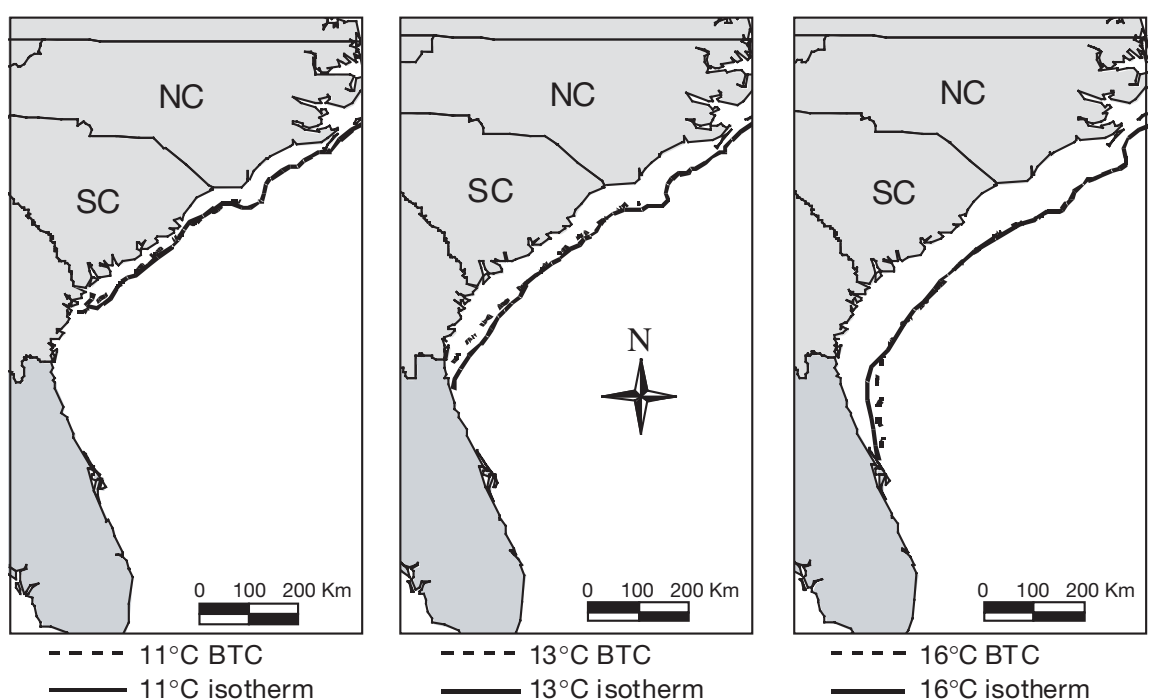

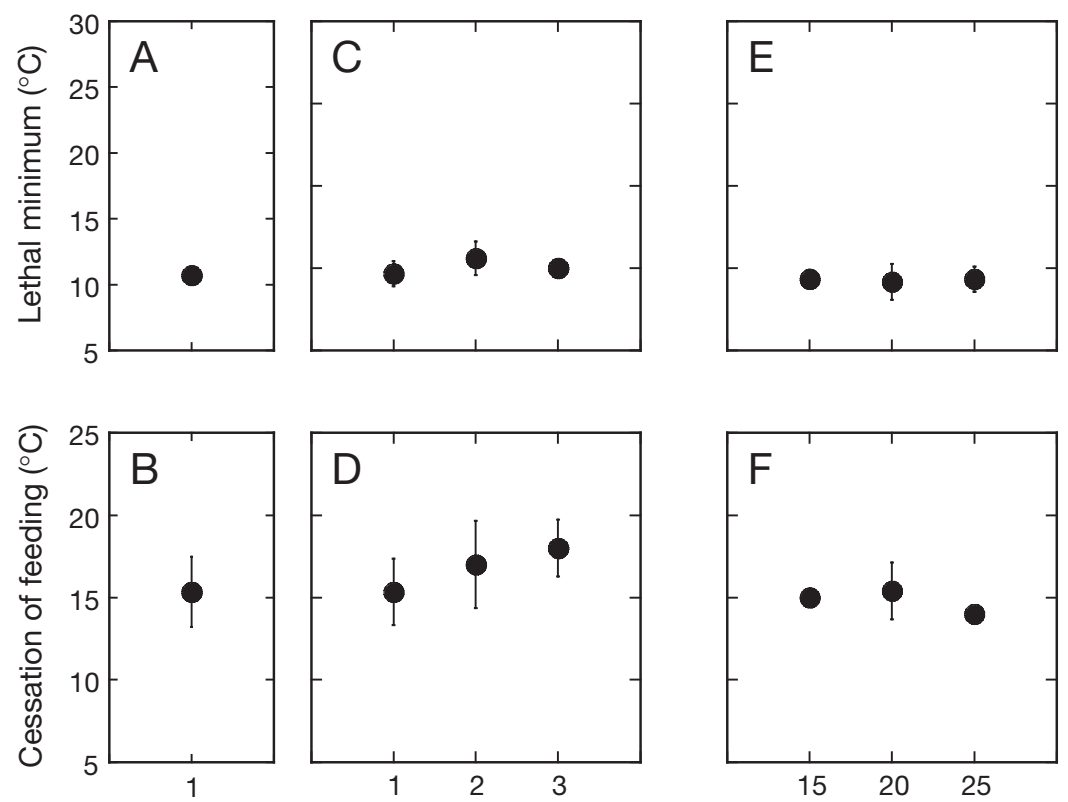

Rate of temperature decrease $\left({ }^{\circ} \mathrm{C} \mathrm{d} \mathrm{d}^{-1}\right)$

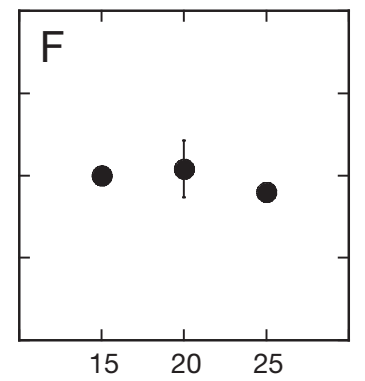

Acclimation temperature $\left({ }^{\circ} \mathrm{C}\right)$

Fig. 4. Pterois volitans/miles complex. Mean $( \pm \mathrm{SE})$ chronic lethal minimum and average temperature at feeding cessation observed for Expts $1(A, B), 2(C, D)$, and $3(\mathrm{E}, \mathrm{F})$

All fish used for experiments involving variable rates of temperature decline fed prior to experimental trials. Fish in the $-3^{\circ} \mathrm{C} \mathrm{d}^{-1}$ group all fed below the initial temperature, however, 2 fish expelled undigested stomach contents just prior to death. In the $-2^{\circ} \mathrm{C} \mathrm{d}^{-1}$ group, 2 fish did not eat for the duration of the trial. Additionally, 1 fish in this group expelled undigested stomach contents just prior to death. All fish in the $-1^{\circ} \mathrm{C} \mathrm{d}^{-1}$ group fed during experimental trials and exhibited feeding behavior similar to fish in Expt 1.

Rate of temperature decline had no effect on lionfish thermal tolerance. The mean CLmin. values for the -3 , -2 and $-1{ }^{\circ} \mathrm{C} \mathrm{d}^{-1}$ treatments were $10.0^{\circ} \mathrm{C}(\mathrm{SD}=0, \mathrm{n}=6)$, $10.6^{\circ} \mathrm{C}(\mathrm{SD}=0.9, \mathrm{n}=5)$, and $9.7^{\circ} \mathrm{C}(\mathrm{SD}=0.6, \mathrm{n}=3)$ (Fig. 4C). No significant effect of temperature decline rate was found on CLmin. comparing the -2 and $-1{ }^{\circ} \mathrm{C}$ $\mathrm{d}^{-1}$ treatments (1-way ANOVA, df $=1, F=2.534$, $\mathrm{p}=0.162)$; the $-3^{\circ} \mathrm{C} \mathrm{d}^{-1}$ data were not included in the ANOVA because the lack of variability. The CLmin. estimates from the -2 and $-1^{\circ} \mathrm{C} \mathrm{d}^{-1}$ were not significantly different from $10^{\circ} \mathrm{C}$, which was the CLmin. estimate from the $-3^{\circ} \mathrm{C} \mathrm{d}^{-1}$ treatment (Student's $t$-test, $\mathrm{df}=$ $4, t=1.501, \mathrm{p}=0.208$; $t$-test, $\mathrm{df}=2, t=1.000, \mathrm{p}=0.423$ ). For the $-3,-2$ and $-1{ }^{\circ} \mathrm{C} \mathrm{d} d^{-1}$ groups, feeding cessation occurred at a mean temperature of $18.0^{\circ} \mathrm{C}(\mathrm{SD}=1.5$, $\mathrm{n}=6), 17.0^{\circ} \mathrm{C}(\mathrm{SD}=2.0, \mathrm{n}=3)$, and $15.3^{\circ} \mathrm{C}(\mathrm{SD}=1.5$, $\mathrm{n}=3$; Fig. 4D). Similarly, no significant effect of temperature decrease was found on the temperature at feeding cessation (ANOVA, $\mathrm{df}=2, F=2.600$, $\mathrm{p}=0.128)$.

\section{Expt 3. Effects of acclimation temperature}

Lionfish exhibited increased activity and feeding behavior at warmer acclimation temperatures during the holding period prior to experimental trials. Fish acclimated to $25^{\circ} \mathrm{C}$ displayed 'normal' behavior (as described in Expt 1) and fed regularly when food was offered. 'Normal' behavior was seen in fish acclimated to $20^{\circ} \mathrm{C}$, but reduced feeding was observed when fish were offered food. Lionfish acclimated to $15^{\circ} \mathrm{C}$ were predominantly stationary throughout the entire holding period and fed infrequently, often abandoning efforts to catch food after a single attempt. All fish at each acclimation temperature fed during the holding period.

During experimental trials, fish acclimated to 25,20 and $15^{\circ} \mathrm{C}$ displayed behavior patterns identical to those observed in Expt 1 as temperature decreased. All fish in the $25^{\circ} \mathrm{C}$ acclimation temperature group fed during experimental trials. Out of 6 fish, 5 fed in the $20^{\circ} \mathrm{C}$ acclimation group, while only 1 fish acclimated to $15^{\circ} \mathrm{C}$, fed during the experimental trial. Several fish in the $15^{\circ} \mathrm{C}$ acclimation group showed interest and attempted to feed, but quickly abandoned any offered food after an initial unsuccessful attempt.

Acclimation temperature had no effect on low temperature tolerance in lionfish. Mean CLmin. values of $9.3^{\circ} \mathrm{C}(\mathrm{SD}=0.3, \mathrm{n}=3), 9.2^{\circ} \mathrm{C}(\mathrm{SD}=1.0, \mathrm{n}=6)$ and $9.3^{\circ} \mathrm{C}$ $\left(\mathrm{SD}=0.5, \mathrm{n}=6\right.$ ) were determined for the $25,20^{\circ} \mathrm{C}$ and $15^{\circ} \mathrm{C}$ acclimation groups (Fig. 4E). Acclimation temperature did not have a significant effect on CLmin. values (ANOVA, df $=2, F=0.088, \mathrm{p}=0.917$ ). Feeding cessation occurred at $14.0^{\circ} \mathrm{C}(\mathrm{SD}=0, \mathrm{n}=3), 15.4^{\circ} \mathrm{C}$ $(\mathrm{SD}=1.5, \mathrm{n}=5)$ and $15.0^{\circ} \mathrm{C}(\mathrm{SD}=0, \mathrm{n}=1)$ for fish held at acclimation temperatures of 25,20 and $15^{\circ} \mathrm{C}$ (Fig. 4F). An ANOVA was not calculated owing to the lack of variability in 2 of the treatment groups; however, 9 of the 10 estimates of the mean temperature of feeding cessation were either 14 or $15^{\circ} \mathrm{C}$, indicating little effect of acclimation temperature.

\section{Distribution and potential overwintering range}

A comparison of winter isotherms with the experimental results indicates that the inshore and northern distribution of lionfish is limited by temperature 
in southeast United States waters. The average CLmin. across all experiments was $10.0^{\circ} \mathrm{C}(\mathrm{SD}=0.9)$. To compare this CLmin. value with median February sea-surface temperatures, February mean and minimum temperatures were compared for the bottom water temperature observations made on the North Carolina shelf (Fig. 1A). Because the mean February temperature was approximately $2^{\circ} \mathrm{C}$ warmer than the minimum February temperature (Table 1), the location of the $12^{\circ} \mathrm{C}$ isotherm from the median February sea-surface temperature image was used to represent the inshore location of the $10^{\circ} \mathrm{C} \mathrm{CLmin}$. of lionfish. Additionally, the bottom-temperature climatology showed the $12^{\circ} \mathrm{C}$ isotherm coinciding with the $200 \mathrm{~m}$ isobath (Fig. 5), indicating that temperature, in conjunction with depth, might be limiting offshore distribution.

Using the $12^{\circ} \mathrm{C}$ sea surface temperature isotherm, the potential range for lionfish in their introduced waters is predicted to extend south from Cape Hatteras onto the shelf of the Gulf of Mexico (Fig. 5). In the Gulf of Mexico and northwards along the Atlantic coast of Florida, the potential distribution extends all the way from the shelf edge to the coast. On the mid- and northern portions of the southeast United States shelf, the potential distribution is restricted to the mid- and outer shelf. Lionfish locations reported since 2000 agree with the predicted potential range boundaries except for 1 observation, which lies directly on the $12^{\circ} \mathrm{C}$ isotherm (Fig. 5).

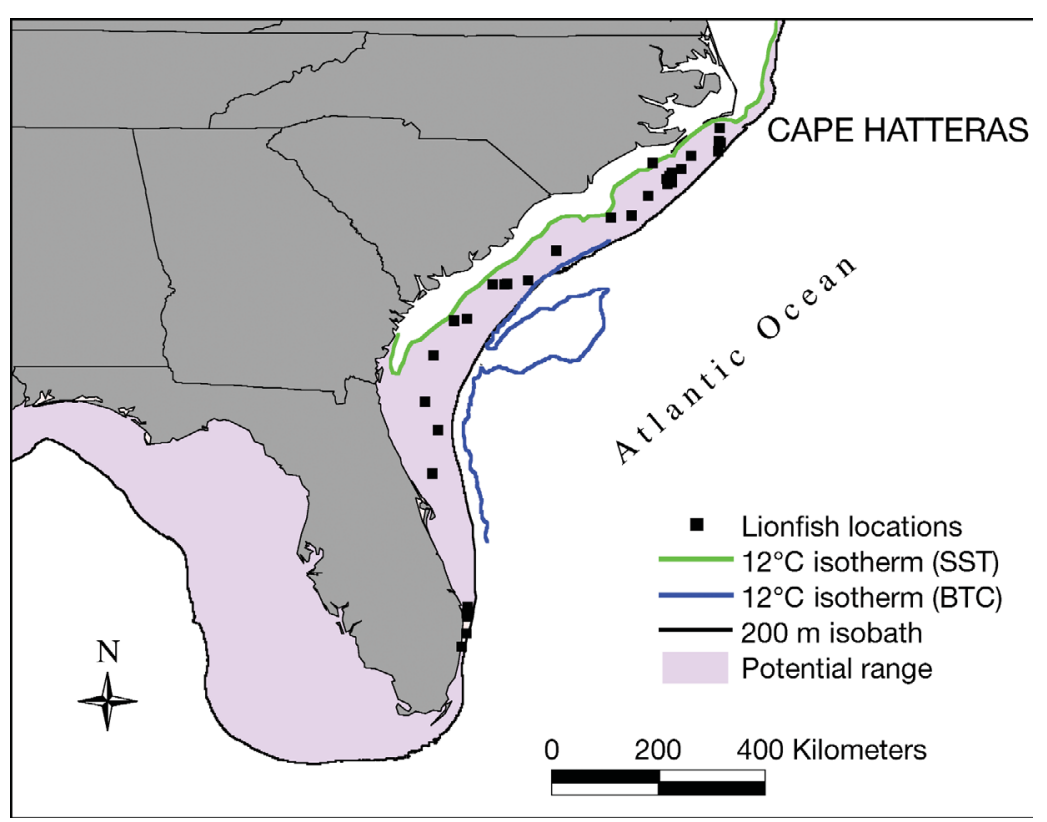

Fig. 5. Pterois volitans/miles complex. Potential range and known lionfish locations on the southeast United States continental shelf. $12^{\circ} \mathrm{C}$ isotherms depicted from sea surface temperature (SST) and bottom temperature climatology (BTC; from Blanton et al. 2003)
Table 1. Mean and minimum bottom temperatures $\left({ }^{\circ} \mathrm{C}\right)$ recorded at 6 North Carolina offshore bottom sites (see Fig. 1) in February 2002. Temperatures were derived from 1344 measurements at each site

\begin{tabular}{|lcc|}
\hline \multirow{2}{*}{ Bottom site } & \multicolumn{2}{c|}{ Temperature $\left({ }^{\circ} \mathrm{C}\right)$} \\
& Mean & Min. \\
\hline Naeco & 17.34 & 15.21 \\
Papoose & 16.42 & 14.66 \\
Atlas & 15.81 & 13.23 \\
Suloid & 12.12 & 10.98 \\
Lobster Wreck & 17.33 & 15.61 \\
Normania & 16.45 & 14.33 \\
\hline
\end{tabular}

\section{DISCUSSION}

An important factor affecting the low temperature tolerance of fishes is rate of temperature change (Beitinger \& McCauley 1990). Ecologically relevant rates of temperature decline $\left(-1\right.$ to $\left.-3^{\circ} \mathrm{C} \mathrm{d}^{-1}\right)$ were found to have no effect on lionfish temperature tolerance. Similar results were observed with Atlantic croaker, where a 5 -fold increase in rate of decline $\left(-0.2\right.$ to $\left.-1.0^{\circ} \mathrm{C} \mathrm{d}^{-1}\right)$ did not affect survival at low temperatures (Lankford \& Targett 2001). Rate of temperature decline also had no effect on low temperature tolerance of American shad Alosa sapidissima $\left(-0.5\right.$ to $-1.9^{\circ} \mathrm{C} \mathrm{d}^{-1}$; Chittenden 1972$)$. However, lionfish temperature tolerance may be affected by faster rates of temperature decline, such as those observed in estuaries during fall and winter.

Acclimation temperature is also thought to be an important factor influencing thermal tolerance in fishes (Lutterschmidt \& Hutchison 1997). A review of previous studies by Beitinger et al. (2000) concluded that lethal thermal limits were strongly affected by thermal history immediately prior to experimentation. Generally, as acclimation temperature increases low temperature tolerance limits also increase (Ward et al. 1993, Currie et al. 1998, Beitinger \& Bennett 2000). Contrary to this general conclusion, low temperature tolerance of lionfish was unaffected by acclimation temperature: differences of $10^{\circ} \mathrm{C}$ between acclimation temperatures produced no significant differences in CLmin. Brett (1956) reported that gain in resistance to low temperatures (i.e. acclimation) is a slow process, with some species requiring up to $20 \mathrm{~d}$ to fully acclimate. Lionfish were held at acclimation temperatures for at least $20 \mathrm{~d}$ (some for more than $40 \mathrm{~d}$ ) prior to 
experimental trials. Other temperature tolerance studies have found no influence of acclimation history on the lower thermal limit (e.g. Young \& Cech 1996), and thus the general conclusion of a positive relationship between acclimation history and thermal tolerance appears not to be universal (e.g. application to tropical fish; Beitinger \& Bennett 2000). However, it is important to note that research on multiple freshwater and marine species has shown that chronic lethal methodology, due to the slow rates of temperature decrease utilized (i.e. $\Delta T \mathrm{~s}$ of ${ }^{\circ} \mathrm{C} \mathrm{d}^{-1}$ rather than $\mathrm{h}^{-1}$ or $\mathrm{min}^{-1}$ ), allows some degree of thermal reacclimation, and therefore could potentially diminish or wholly cancel the effects of acclimation temperature on low temperature tolerance (Lutterschmidt \& Hutchison 1997, Beitinger et al. 2000).

The potential range distribution reported here (Fig. 5) is based on the chronic lethal minimum of lionfish determined in the laboratory. In the field, minimum tolerable temperatures may be higher owing to long-term bioenergetic costs of prolonged exposure to low sublethal temperatures, and the effects of feeding cessation at temperatures higher than the chronic lethal minimum (e.g. Hurst \& Conover 2002). Further, the range distribution predicted here was based on a $50 \mathrm{yr}$ average of bottom water temperature and a 9 yr median of sea surface temperature. Interannual variability in temperature will result in interannual variability in the distribution of thermally suitable habitat. Similarly, long-term changes in ocean temperature will result in extensions or contractions in the range of lionfish along the east coast of the United States. The data presented here should be viewed as placing the lionfish invasion in context with the zoogeography of the western Atlantic Ocean (Briggs 1974), albeit with laboratoryderived estimates of thermal limits.

Combining the thermal tolerance of lionfish with hydrographic characteristics of the Atlantic coast of the United States defines the northern limit of lionfish distribution. Thermal tolerances determined here and the occurrence of all reported adult lionfish sightings off the coasts of North Carolina, South Carolina, Georgia and Florida supports Cape Hatteras as the northern range limit of lionfish along the east coast of North America (Fig. 5). Juvenile lionfish have been observed on the northeast United States continental shelf during summer, but fish in these locations could not survive winter temperatures based on the CLmin. values reported here. McBride \& Able (1998) reported a similar fate for spotfin butterflyfish Chaetodon ocellatus in New Jersey estuaries during winter, where juveniles were found to stop eating at $12^{\circ} \mathrm{C}$ and perish at temperatures below $10^{\circ} \mathrm{C}$.
Water temperature also limits the inshore distribution of lionfish on the southeast United States continental shelf. The inshore portions of the southeast shelf are too cold for overwinter survival, but the offshore portions of the shelf remain warm. This winter-time crossshelf gradient is caused by heating of shelf waters at their offshore edge by the Gulf Stream (Barnard et al. 1997) and heat-loss across the entire shelf owing to air-sea interactions (Atkinson 1985). The overwintering habitat extends closer to shore southward, from Cape Hatteras to southeast Florida (Fig. 5), as the shelf narrows and winter heat-loss to the atmosphere decreases.

The offshore limit of the lionfish invasion may be linked to temperature tolerance, depth, or a combination of both factors. Lionfish are reported from shore $(0 \mathrm{~m})$ to $50 \mathrm{~m}$ in their native range (Schultz 1986). Along the southeast United States continental shelf, the majority of lionfish have been observed between 35 and $45 \mathrm{~m}$, with a maximum observed depth of $80 \mathrm{~m}$ (Whitfield et al. 2002). The $12^{\circ} \mathrm{C}$ average bottom temperature isotherm is coincident with the shelf break $(200 \mathrm{~m})$, and thus the limiting factor, depth or temperature, cannot be resolved (Fig. 5). An offshore deviation in bottom water temperature is present off the South Carolina coast that encompasses the Charleston Bump, with depths between 400 and $600 \mathrm{~m}$ (Fig. 5). Thus, based on thermal limits alone, lionfish could survive on the Charleston Bump, but again depth could be limiting.

The southern extent of the lionfish introduction is not currently limited by temperature. The distribution of lionfish in the western Pacific and Indian Oceans extends across nearly $70^{\circ}$ of latitude (roughly $35^{\circ} \mathrm{S}$ to $35^{\circ} \mathrm{N}$; Schultz 1986, Golani \& Sonin 1992) and coincides with the zoogeographic distribution of the tropical and sub-tropical faunas (Briggs 1974). The application of the southern native range limits to the western Atlantic Ocean indicates that lionfish could potentially be distributed in the Gulf of Mexico, throughout the Caribbean Sea and southward along the coast of Brazil (Briggs 1974). However, lionfish distribution is presently limited to the southeast United States continental shelf north of Miami, Florida, and this southern limit is probably attributable to the site of initial lionfish introduction. All available evidence indicates that the introduction of lionfish resulted from aquarium releases (Courtenay 1995, Whitfield et al. 2002, Hare \& Whitfield 2003). Releases along the east coast of Florida would result in larval and juvenile transport northward along the southeast United States shelf (Hare et al. 2002), explaining the present distribution of lionfish (Fig. 5). The apparent absence of lionfish south of Miami indicates that southward dispersal mechanisms are limited or absent at the initial introduction site. An 
introduction site along the Florida Keys, Gulf of Mexico coast, Caribbean Sea or Brazilian coast would probably be necessary for the establishment of lionfish south of Florida. An alternative is that the southern limit is controlled by thermal limitation at high temperatures, but this is unlikely owing to the cross-equatorial distribution of lionfish in their native range (Schultz 1986).

The introduction of lionfish along the Atlantic coast of the United States illustrates several important factors concerning marine fish invasions. Characteristics of fish in their native range cannot always be directly applied to their introduced habitats and are often a poor predictor of performance in a novel setting (Ruiz et al. 1997). For example, while the depth range of lionfish is shore $(0 \mathrm{~m})$ to $50 \mathrm{~m}$ in the Indo-Pacific (Schultz 1986), lionfish have been observed as deep as $80 \mathrm{~m}$ along the southeast United States. Additionally, in their native range, lionfish are distributed on continental shelves adjacent to western boundary currents in both the northern and southern hemispheres (Schultz 1986), while in their introduced range, lionfish are distributed primarily on the northern portion of the continental shelf adjacent to a western boundary current, in the northern hemisphere only. This limited distribution probably results from an interaction between the initial introduction site and the natural limits of fish dispersal in the introduced system. Although limited in a zoogeographic sense, the spread of lionfish along the entire southeast United States continental shelf occurred quickly; the area of thermally appropriate habitat was occupied within the scale of 1 to $10 \mathrm{yr}$ (Whitfield et al. 2002, Hare \& Whitfield 2003). This rapid spread of lionfish demonstrates the dispersal potential of marine fishes with planktonic larvae and illustrates the consequences of this dispersal potential once introduced marine fish start reproducing in their adopted ecosystems. Further, the absence of lionfish south of Miami indicates the combined role of release location, dispersal mechanisms and appropriate habitat in determining the distribution of invasive species in marine ecosystems.

Acknowledgements. This research was a combined effort of the NOAA Beaufort Laboratory, North Carolina State University, and Oak Ridge Institute for Science and Education. Funding was provided by the National Marine Fisheries Service and National Ocean Service. We thank the faculty, staff, and students of the North Carolina State University Department of Zoology, and the staff of the NOAA Beaufort Laboratory, especially J. A. Morris, C. W. Krouse, R. L. Ferguson and F. J. Hernandez. R. Jones and the staff of the North Carolina Aquarium at Pine Knoll Shores also provided invaluable advice and assistance regarding lionfish husbandry. B. Blanton and K. Pherson Edwards (University of North Carolina, Chapel Hill) kindly provided water temperature climatology data for the southeast United States. J. Govoni, A. Powell, M. Wuenschel and P. Marraro reviewed earlier drafts of this manuscript.

\section{LITERATURE CITED}

Atkinson LP (1985) Hydrography and nutrients of the southeastern U.S. continental shelf. In: Atkinson LP, Menzel DW, Bush KA (eds) Oceanography of the southeastern U.S. Continental Shelf. American Geophysical Union, Washington, DC

Baker SC, Heidinger RC (1996) Upper lethal temperature tolerance of black crappie. J Fish Biol 48:1123-1129

Baltz DM (1991) Introduced fishes into marine systems and inland seas. Biol Conserv 56:151-177

Barnard AH, Stegmann PM, Yoder JA (1997) Seasonal surface ocean variability in the South Atlantic Bight derived from CZCS and AVHRR imagery. Cont Shelf Res 17: 1181-1206

Becker CD, Genoway RG (1979) Evaluation of the critical thermal maximum for determining thermal tolerance of freshwater fish. Environ Biol Fish 4:245-256

Beitinger TL, Bennett WA (2000) Quantification of the role of acclimation temperature in temperature tolerance of fishes. Environ Biol Fish 58:277-288

Beitinger TL, McCauley RW (1990) Whole-animal physiological processes for the assessment of stress in fishes. J Gt Lakes Res 16:542-575

Beitinger TL, Bennett WA, McCauley RW (2000) Temperature tolerances of North American freshwater fishes exposed to dynamic changes in temperature. Environ Biol Fish 58: 237-275

Bennett WA, Judd FW (1992) Factors affecting the lowtemperature tolerance of Texas pinfish. Trans Am Fish Soc 121:659-666

Bennett WA, Currie RJ, Wagner PF, Beitinger TL (1997) Cold tolerance and potential overwintering of the red-bellied piranha Pygocentrus nattereri in the United States. Trans Am Fish Soc 126:841-849

Blanton BO, Aretxabaleta A, Werner FE, Seim H (2003) Monthly climatology of the continental shelf waters of the South Atlantic Bight. J Geophys Res 108:3264 doi:10.1029/2002JC001609

Brett JR (1956) Some principles in the thermal requirements of fishes. Q Rev Biol 31:75-87

Briggs JC (1974) Marine zoogeography. McGraw Hill, New York

Chittenden ME (1972) Responses of young American shad, Alosa sapidissima, to low temperatures. Trans Am Fish Soc 101:680-685

Cossins AR, Bowler K (1987) Temperature biology of animals. Chapman \& Hall, New York

Courtenay WR (1995) Marine fish introductions in southeastern Florida. Newsl Am Fish Soc Introduced Fish Sect $14: 2-3$

Currie RJ, Bennett WA, Beitinger TL (1998) Critical thermal minima and maxima of three freshwater game-fish species acclimated to constant temperatures. Environ Biol Fish 51:87-200

Doudoroff P (1942) The resistance and acclimatization of marine fishes to temperature changes. I. Experiments with Girella nigricans (Ayres). Biol Bull (Woods Hole) 83:219-244

Elliott JM (1981) Some aspects of thermal stress on freshwater teleosts. In: Pickering AD (ed) Stress in fish. Academic Press, London, p 209-245

Erdmann MV, Vagelli A (2001) Banggai cardinalfish invade Lembeh Strait. Coral Reefs 20:252-253

Fields R, Lowe SS, Kaminski C, Whitt GS, Philipp DP (1987) Critical and chronic thermal maxima of northern and Florida largemouth bass and their reciprocal F1 and F2 hybrids. Trans Am Fish Soc 116:856-863 
Fishelson L (1975) Ethology and reproduction of pteroid fishes found in the Gulf of Aqaba (Red Sea), especially Dendrochirus brachypterus (Cuvier), (Pteroidae, Teleostei). Pubbl Stn Zool Napoli 39(Suppl 1):635-656

Fishelson L (1997) Experiments and observations on food consumption, growth and starvation in Dendrochirus brachypterus and Pterois volitans (Pteroinae, Scorpaenidae). Environ Biol Fish 50:391-403

Fry FEJ (1971) The effect of environmental factors on the physiology of fish. In: Hoar WS, Randall DJ (eds) Fish physiology, VI: Environmental relations and behavior. Academic Press, New York, p 1-98

Golani D, Sonin O (1992) New records of the Red Sea fishes, Pterois miles (Scorpaenidae) and Pteragogus pelycus (Labridae) from the Eastern Mediterranean Sea. Jpn J Ichthyol 39:167-169

Hare JA, Whitfield PE (2003) An integrated assessment of the introduction of lionfish (Pterois volitans/miles complex) to the Western Atlantic Ocean. NOAA Tech Memo NOS NCCOS 2 (available from authors)

Hare JA, Churchill JH, Cowen RK, Berger $\mathrm{T}$ and 5 others (2002) Routes and rates of larval fish transport from the southeastern to the mid-Atlantic North American continental shelf. Limnol Oceanogr 47:1774-1789

Hurst TP, Conover DO (2002) Effects of temperature and salinity on survival of young-of-the-year Hudson River striped bass (Morone saxatilis): implications for optimal overwintering habitat. Can J Fish Aquat Sci 59:787-795

Kahru M (2001) Windows image manager: image display and analysis program for Microsoft Windows with special features for satellite images. San Diego, CA

Kochzius M, Soller R, Khalaf MA, Blohm D (2003) Molecular phylogeny of the lionfish genera Dendrochirus and Pterois (Scorpaenidae, Pteroinae) based on mitochondrial DNA sequences. Mol Phylogenet Evol 28:396-403

Lankford TL, Targett TE (2001) Low-temperature tolerance of age-0 Atlantic croakers: recruitment implications for U.S. Mid-Atlantic Estuaries. Trans Am Fish Soc 130:236-249

Lutterschmidt WI, Hutchison VH (1997) The critical thermal maximum: history and critique. Can J Zool 75:1561-1574

McBride RS, Able KW (1998) Ecology and fate of butterflyfishes, Chaetodon spp., in the temperate western north Atlantic. Bull Mar Sci 63:401-416

Mora C, Ospina AF (2002) Experimental effect of cold, La Niña

Editorial responsibility: Otto Kinne (Editor),

Oldendorf/Luhe, Germany temperatures on the survival of reef fishes from Gorgona Island (eastern Pacific Ocean). Mar Biol 141:789-793

Parker RO, Dixon RL (1998) Changes in a North Carolina reef fish community after 15 years of intense fishing - global warming implications. Trans Am Fish Soc 127:908-920

Prentice JA (1989) Low-temperature tolerance of southern flounder in Texas. Trans Am Fish Soc 118:30-35

Randall JE (1987) Introductions of marine fishes to the Hawaiian Islands. Bull Mar Sci 41:490-502

Ruiz GM, Carlton JT, Grosholz ED, Hines AH (1997) Global invasions of marine and estuarine habitats by nonindigenous species: mechanisms, extent, and consequences. Am Zool 37:621-632

Schultz ET (1986) Pterois volitans and Pterois miles: two valid species. Copeia 1986(3):686-690

Schwartz FJ (1963) Effects of winter water conditions on two species of marine fishes. Ecology 44:622-623

Schwartz FJ (1964) Effects of winter water conditions on fifteen species of captive marine fishes. Am Midl Nat 71: $434-444$

Semmens BX, Buhle ER, Salomon AK, Pattengill-Semmens CV (2004) A hotspot of non-native marine fishes: evidence for the aquarium trade as an invasion pathway. Mar Ecol Prog Ser 266:239-244

Shafland PL, Pestrak JM (1982) Lower lethal temperatures for fourteen non-native fishes in Florida. Environ Biol Fish $7: 149-156$

Stegmann PM, Yoder JA (1996) Variability of sea-surface temperature in the South Atlantic Bight as observed from satellite: implications for offshore-spawning fish. Cont Shelf Res 16:843-861

Ward R, Blandon IR, King TL, Beitinger TL (1993) Comparisons of critical thermal maxima and minima of juvenile red drum (Sciaenops ocellatus) from Texas and North Carolina. Northeast Gulf Sci 13:23-28

Whitfield PE, Gardner T, Vives SP, Gilligan MR, Courtenay WR, Ray GC, Hare JA (2002) Biological invasion of the Indo-Pacific lionfish Pterois volitans along the Atlantic coast of North America. Mar Ecol Prog Ser 235:289-297

Young PS, Cech JJ (1996) Environmental tolerances and requirements of splittail. Trans Am Fish Soc 125:664-678

Zale AV, Gregory RW (1989) Effect of salinity on cold tolerance of juvenile blue tilapias. Trans Am Fish Soc 118: $718-720$

Submitted: December 15, 2003; Accepted: August 3, 2004

Proofs received from author(s): November 24, 2004 